\title{
WestVirginiaUniversity
}

THE RESEARCH REPOSITORY @ WVU

West Virginia Agricultural and Forestry Experiment

Davis College of Agriculture, Natural Resources

Station Bulletins

And Design

$1-1-1966$

\section{Breed as a factor in the production of ewes retained for flock replacement}

C. J. Cunningham

J.A. Welch

J O. Heisham

Follow this and additional works at: https://researchrepository.wvu.edu/ wv_agricultural_and_forestry_experiment_station_bulletins

\section{Digital Commons Citation}

Cunningham, C. J.; Welch, J. A.; and Heisham, J O., "Breed as a factor in the production of ewes retained for flock replacement" (1966). West Virginia Agricultural and Forestry Experiment Station Bulletins. 533.

https://researchrepository.wvu.edu/wv_agricultural_and_forestry_experiment_station_bulletins/488 @ WVU. It has been accepted for inclusion in West Virginia Agricultural and Forestry Experiment Station Bulletins by an authorized administrator of The Research Repository @WVU. For more information, please contact ian.harmon@mail.wvu.edu. 
West Virginia University Libraries

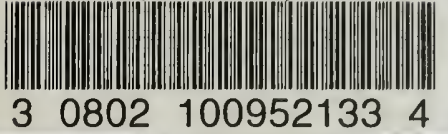


Digitized by the Internet Archive in 2010 with funding from Lyrasis Members and Sloan Foundation 


\section{BULLETIN 533}

\section{SEPTEMBER, 1966}

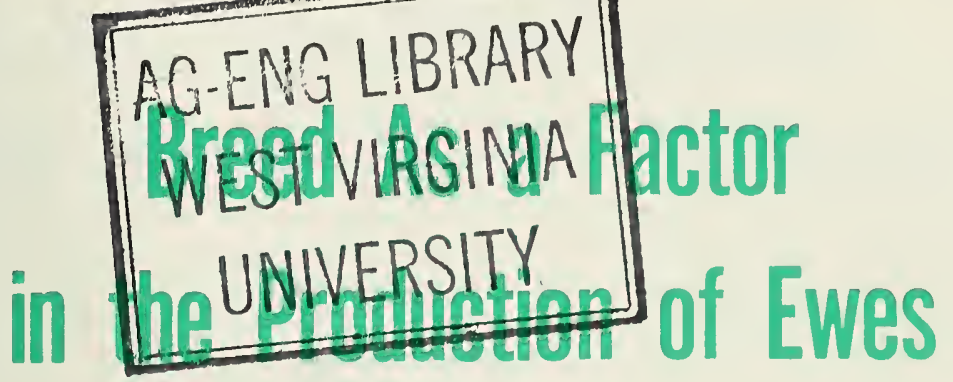

Retained for Flock Replacement

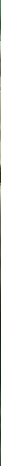

\section{West Virginia University Igiculltual Experiment Station:}




\section{THE AUTHORS}

C. J. Cunningham is Station Animal Husbandman in charge of Reymann Memorial Farms Substation; J. A. Welch is Station Animal Husbandman; and J. O. Heishman is Associate Station Animal Pathologist, Reymann Memorial Farms Substation.

\section{ACKNOWLEDGMENT}

The authors wish to thank Dr. E. K. Inskeep and Mr. J. B. Andrick for the statistical analyses of the data, and Dr. James L. McBee Jr., and Mr. B. W. Wamsley, Jr. for their help with grading the lambs.

West VIRGINIA UnIVERSITY Agricultural Experiment Station College of Agriculture and Forestry

A. H. Vanlandingham, Director

Morgantown 


\section{Breed As a Factor in the Production Of Ewes Retained for Flock Replacement}

C. J. CUNNINGHAM, J. A. WELCH, and J. O. HEISHMAN URING THE DECADE from 1940 to 1950 large numbers of ewes 1 for flock replacements were brought into West Virginia from the western part of the United States. These western ewes were larger and thriftier than the native ewes and proved to be more profitable, as indicated by a study by Livesay and Cunningham (1). As time passed good western ewes became more difficult to obtain and more expensive. The question arose as to how suitable flock replacements could best be obtained from the ewes purchased from the West.

The data presented in this bulletin were collected over a period of six years starting with the breeding season of 1954. The flock was kept at the Reymann Memorial Farms, a substation of the West Virginia University Agricultural Experiment Station, located at Wardensville.

\section{Experimental Procedure}

Ewes used in this study were the offspring of ewes purchased in California in 1951 as yearling lambs. The western ewes were of Hampshire X Rambouillet and Suffolk X Rambouillet breeding. They were divided into three equal groups and bred to Hampshire, Dorset, and Corriedale rams. As near as possible an equal number of the top ewe lambs from each mating were retained each year for flock replacement. Sufficient ewe lambs were kept to maintain the flock at its original number.

Ewe lambs were bred to a Southdown ram in the fall of their first year. Thereafter they were divided into different groups and bred to either Corriedale, Dorset, or Hampshire rams as indicated in Table 1. Data on the performance of ewes bred to Southdown rams is not included in this study.

Each year the different groups were pasture bred, allowing a twomonth breeding season beginning in early September. After the breeding period the three groups of ewes were put together and treated as one flock. Lambs were born in a barn and were weighed and ear-tagged at birth and were docked and castrated when one to two weeks old. All lambs were creep-fed a grain mixture consisting of 50 per cent cracked corn and 50 per cent whole oats by weight. 
TABLE 1

Breeding Pattern Followed

\begin{tabular}{|c|c|c|c|c|c|c|}
\hline \multirow{2}{*}{$\begin{array}{l}\text { Breed of } \\
\text { Ewe's Sire }\end{array}$} & \multicolumn{6}{|c|}{ Year } \\
\hline & 1954 & 1955 & 1956 & 1957 & 1958 & 1959 \\
\hline Corriedale & C. & D. & H., D. & D. & D., H. & D., H. \\
\hline Hampshire & H. & H. & H., D. & $\mathrm{H}$. & D., H. & D., H. \\
\hline Dorset & D. & D. & D. & D., H. & D., H. & D., H. \\
\hline $\begin{array}{l}\text { Hampshire } \\
\qquad \begin{array}{c}\text { Hampshire } \\
\text { grandsire }\end{array}\end{array}$ & & & H., D. & H. & D., H. & D., H. \\
\hline $\begin{array}{l}\text { Dorset } \\
+ \text { Dorset } \\
\text { grandsire }\end{array}$ & & . & D. & D. & D., H. & D., H. \\
\hline
\end{tabular}

Parasite control measures consisted of feeding free choice a mixture of one part phenothiazine and nine parts salt. In addition, each ewe received 25 grams of phenothiazine before going to pasture and again in the fall about two weeks before breeding. When necessary all sheep were sprayed to control external parasites.

Lambs were marketed each year in two drafts. Just before marketing the lambs were graded by a committee consisting of a University staff member, a Reymann Memorial Farms staff member, and an "official" lamb grader employed by the West Virginia Livestock Marketing Association. Federal standards for grading of slaughter lambs were used. The lambs were graded to the nearest whole grade and each grade was assigned a numerical value. Values assigned during 1955 through 1958 were: prime and choice grades-1; good-2; medium-3; plain-4; and cull-5. In 1959 and 1960 prime and choice were separated so that the value ranged from 1 (prime) to 6 (cull). Each committee member scored each lamb individually and the average of the scores to the nearest grade was the lamb's final grade.

All data on lamb performance, lambing rates, lamb mortality, and wool weights were recorded on IBM cards. Analysis of variance was used to test for differences in performance traits of ewes and lambs due to breed of sire of the ewes. Effects (both main effects and interactions) of sex and type of birth or rearing on lamb performance were either separated out in the analysis of variance or, in the case of average daily gain, adjusted for prior to analysis, by the factors given in West Virginia 
Station Bulletin 505 by Cunningham $c t a l$. (2). The lambs studied therein included the ewes studied here and their mates of similar breeding and other lambs born and raised side by side with the lambs studied here. Lambs that were raised as singles gained $0.07 \mathrm{lbs}$. more per day than lambs raised as twins, and wether lambs gained $0.03 \mathrm{lbs}$. more per day than ewes. Almost identical figures were reported earlier in Virginia Bulletin 492 (3).

The lack of two generations of Hampshire and Dorset breeding in the first two years of this study and the year-to-year change in breeding pattern prevented the efficient use of least squares analysis as a method of adjustment for sex, type, and year of birth as had been done in the studies reported in the two bulletins cited above.

In the eases of lambs born and raised, lamb mortality, and number of barren ewes, data for the three single-bred groups were pooled over the six years for analysis and data for all five breeding groups over the last four years were pooled for a separate analysis.

\section{Results and Discussion}

On the whole, differences between the five different breeding groups in lambing performance and in the productivity of their lambs were small and inconsistent from year to year during the six-year study. The comparisons drawn in 1954-55, when the ewes were bred to rams of their own breeds, and in 1958-59 and 1959-60, when all ewes were divided about equally among Dorset and Hampshire rams, are the most meaningful.

\section{LAMB CROP}

Differences due to breed of ewe in the number of lambs born and raised to weaning per ewe (Table 2 ) were not significant by either analysis ( 3 breed groups over 6 years; 5 groups over last 4 years). Corriedale-sired ewes dropped on the average 1.54 lambs per ewe bred and raised 1.37 per ewe to marketing. Hampshire-sired ewes gave birth to 1.38 lambs per ewe bred and raised 1.15 of these. The Dorset-sired ewes dropped 1.40 lambs per ewe and raised 1.27 to market age.

The double-bred Dorset and Hampshire ewes tended to bear and raise fewer lambs per ewe than did the single-bred ewes, but this trend was due in large part to the fact that these ewes were, on the whole, younger than the single-bred ewes during the period of this study.

\section{MORTALITY}

Differences in the percentage of lamb mortality (Table 3) from birth to weaning were not significant among the breeds of ewes studied. 


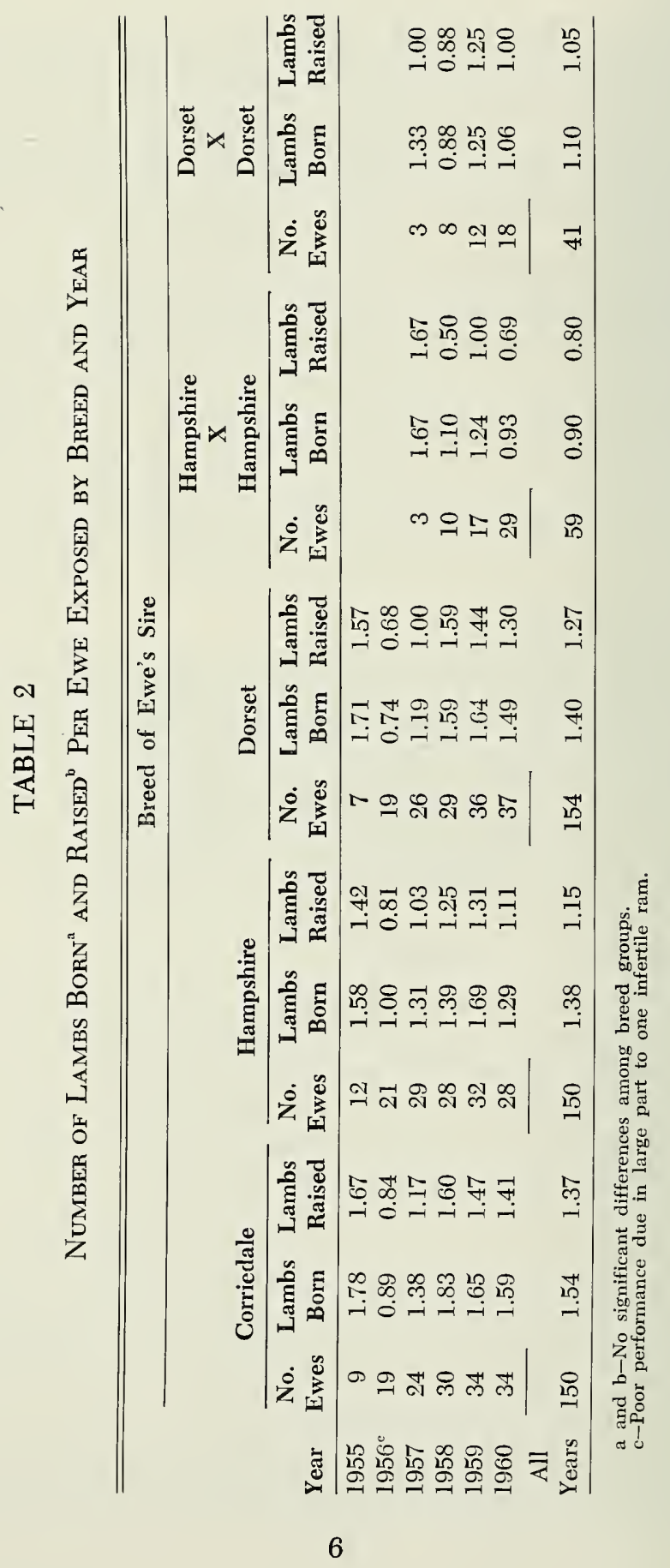




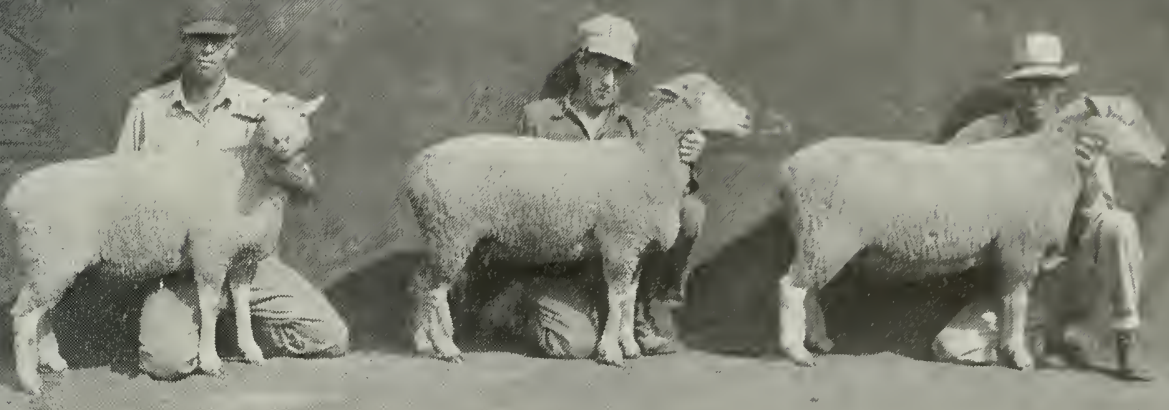

$x-1$

DORSET-SIRED EWES

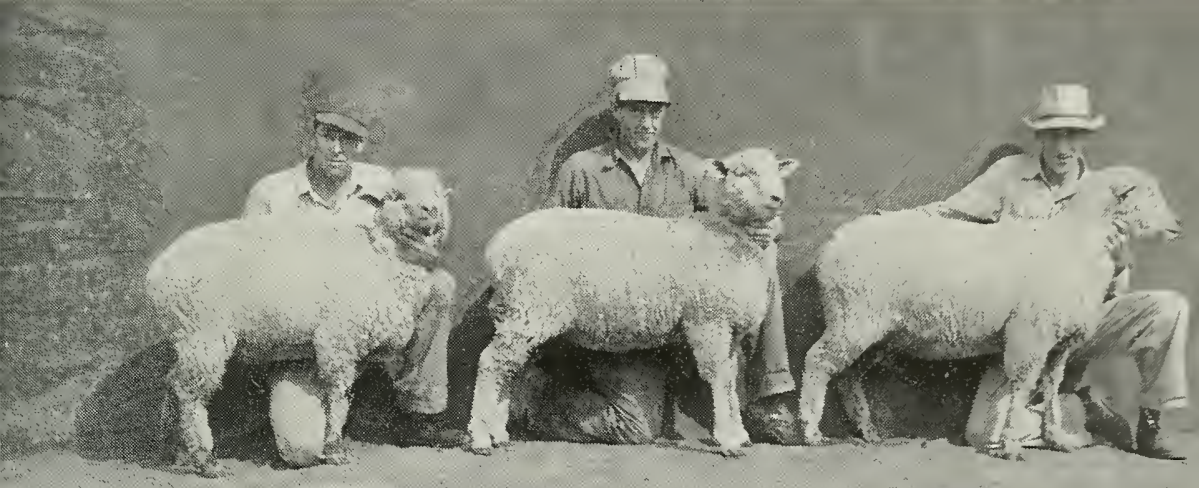

\section{CORRIEDALE-SIRED EWES}

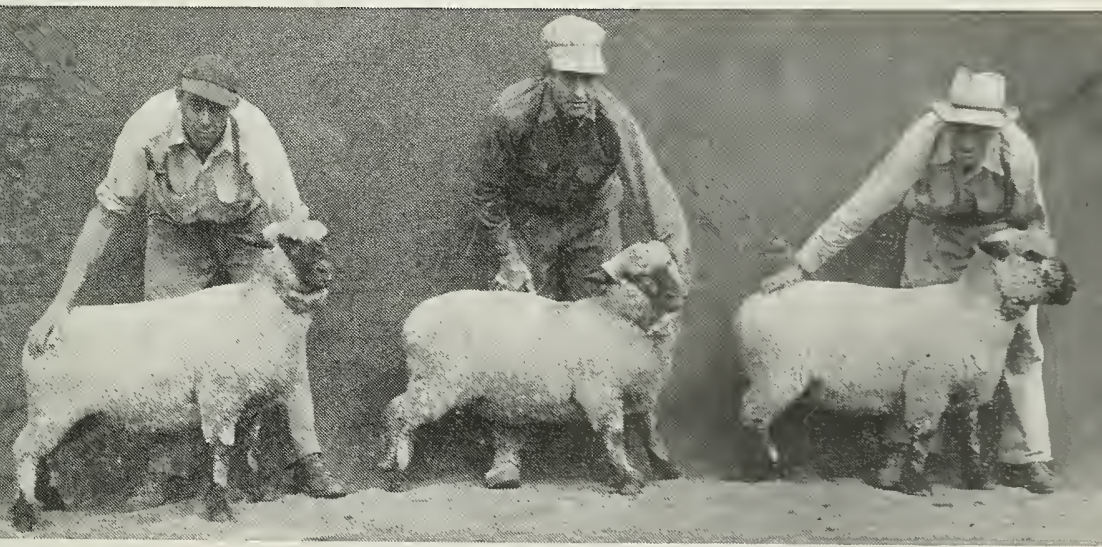

HAMIPSHIRE-SIRED EWES 
TABLE 3

Per Cent Lanib Mortality by Breed and Year

\begin{tabular}{lccccc}
\hline & & & Hampshire & $\begin{array}{c}\text { Dorset } \\
\mathbf{X}\end{array}$ \\
Year & Corriedale & Hampshire & Dorset & Hampshire & $\begin{array}{c}\text { Dorset } \\
1955\end{array}$ \\
\hline 1956 & 5.2 & 10.5 & 8.3 & & \\
1957 & 15.1 & 19.0 & 7.1 & & \\
1958 & 12.7 & 21.0 & 16.1 & 0.0 & 25.0 \\
1959 & 10.7 & 10.2 & 0.0 & 54.5 & 0.0 \\
1960 & 11.1 & 22.2 & 11.8 & 23.5 & 0.0 \\
All Years & $11.2(231)^{\mathrm{a}}$ & 13.8 & 12.7 & 35.0 & 5.2 \\
\hline
\end{tabular}

a-Number lambs born in parentheses. $(\mathrm{P}<0.10)$.

$\mathrm{b}-$ No significant differences. Group $\mathrm{D}(1)$ tended to show less mortality than group $\mathrm{H}(2)$

c-Percentages were transformed to angles for analysis.

(1) in footnote ${ }^{b}=$ Dorset.

(2) in footnote $^{b}=$ Hampshire.

However, the lambs from both the single- and double-Dorset-sired ewes tended to show less mortality than the corresponding Hampshire groups $(\mathrm{P}<0.10$ in the case of single-bred $)$.

The Dorset-sired ewes produced 217 lambs during the six years of this study, of which 196 reached market age, a mortality of 9.7 per cent, the lowest of the three single-bred groups of ewes studied. All the Dorset lambs dropped during one year (1958) reached market. Corriedale-sired ewes produced 231 lambs with 204 reaching market age, a mortality of 11.2 per cent, and Hampshire-sired ewes produced 207 lambs with 172 reaching market age, a mortality of 16.9 per cent. A trend toward higher mortality of lambs from Hampshire ewes was noted also in the earlier work of Livesay and Cunningham (1).

\section{BIRTH WEIGHT}

The mean birth weights for the lambs from the ewes sired by the different breeds for the six-year period were $9.0 \mathrm{lbs}$. for the Corriedale, 9.6 lbs. for the Hampshire, and 9.0 for the Dorset. The double-bred Hampshire ewes had lambs with an average birth weight of $8.7 \mathrm{lbs}$. and the double-bred-Dorset, $8.6 \mathrm{lbs}$.

Hampshire-sired ewes produced lambs that were heavier at birth $(\mathrm{P}<0.05)$ than lambs from the Corriedale-sired ewes in three out of the six years and lambs that were heavier than those of the Dorset-sired ewes in two of the six years. The birth weights of lambs from the Hampshiresired ewes were significantly heavier when compared to lambs from double-bred Hampshire $(\mathrm{P}<0.05)$ and double-bred Dorset $(\mathrm{P}<0.01)$ 
TABLE 4

Average Birth Weight by Breed of Dam's Sire and Year ${ }^{\text {r }}$

\begin{tabular}{lccccc}
\hline \hline Year & Corriedale & Hampshire & Dorset & $\begin{array}{c}\text { Hampshire } \\
\text { Xampshire }\end{array}$ & $\begin{array}{c}\text { Dorset } \\
\text { X } \\
\text { Dorset }\end{array}$ \\
\hline $1955^{\mathrm{b}}$ & $8.0(15)^{\mathrm{a}}$ & $9.2(17)$ & $8.2(11)$ & & \\
$1956^{\mathbf{e}}$ & $8.6(16)$ & $10.4(17)$ & $8.9(13)$ & & \\
$1957^{\mathrm{a}}$ & $9.6(28)$ & $9.5(30)$ & $9.3(26)$ & $8.2(5)$ & $8.4(3)$ \\
$1958^{\mathrm{e}}$ & $8.8(48)$ & $10.6(35)$ & $9.0(46)$ & $9.2(5)$ & $8.6(7)$ \\
$1959^{\mathrm{a}}$ & $9.1(52)$ & $8.8(43)$ & $8.8(52)$ & $8.0(19)$ & $8.5(15)$ \\
$1960^{\mathbf{a}}$ & $9.1(48)$ & $9.5(33)$ & $9.3(50)$ & $9.6(17)$ & $8.7(18)$ \\
\hline
\end{tabular}

a-Number of lambs in parentheses.

$\mathrm{b}-\mathrm{H}>\mathrm{C} \quad(\mathrm{P}<0.05)$;

$\mathrm{C}-\mathrm{H}>\mathrm{C}$ and $\mathrm{D}(\mathrm{I}) \quad(\mathrm{P}<0.05)$.

$\mathrm{d}-\mathrm{No}$ significant differences.

$\mathrm{d}-\mathrm{H}>\mathrm{C}, \mathrm{D}$ and $\mathrm{DD}(2)(\mathrm{P}<0.01) ; \mathrm{H}>\mathrm{HH}(3)(\mathrm{P}<0.05)$.

f-Differences due to sex and type of birth and interactions of these with breed were separated before testing for breed differences.

(1) $\mathrm{D} \equiv$ Dorset. $\mathrm{D}$ Dorset (double bred).

(3) $\mathrm{HH} \equiv$ Hampshire X Hampshire (double bred).

ewes in one year (Table 4). Thus Hampshire-sired dams appear to provide a birth weight advantage to their lambs just as do Hampshire sires to their lambs, Carter et al. (3), and Cunningham et al. (2).

\section{AVERAGE DAILY GAIN}

The mean adjusted average daily gains (lbs.) of lambs from the ewes sired by the various breeds of rams in this study were: Corriedale, .59; Hampshire, .60; Dorset, .60; double-bred Hampshire, .58; and doublebred Dorset, .59. There were no significant differences in the performance of lambs from any of the breeds of ewes in the average daily gains in four of the six years of this study. However, in 1955 (Table 5) the Hampshire-sired ewes produced lambs that gained faster than the lambs from Corriedale-sired $(\mathrm{P}<0.01)$ ewes. Also in this same year, the lambs from the Dorset-sired ewes gained faster $(\mathrm{P}<0.05)$ than lambs from the Corriedale-sired ewes. In 1956, lambs produced by the Dorset-sired ewes gained faster $(\mathrm{P}<0.05)$ than the lambs from the Corriedale-sired ewes.

\section{SLAUGHTER GRADE}

There were only slight differences in grades of the lambs produced by the various breeds of ewes studied. No significant differences existed in four of the six years this work was in progress. However, in 1956 the Dorset-sired ewes produced lambs that graded significantly higher than the lambs from Corriedale-sired ewes at the 1 per cent level, and the lambs from the Hampshire ewes graded higher than the Corriedale at the 


\section{TABLE 5}

Adjusted Average Daily Gain ${ }^{\mathrm{e}}$ by Breed of Dam’s Sire and Year

\begin{tabular}{|c|c|c|c|c|c|}
\hline Year & Corriedale & Hampshire & Dorset & $\begin{array}{c}\text { Hampshire } \\
\mathrm{X} \\
\text { Hampshire }\end{array}$ & $\begin{array}{c}\text { Dorset } \\
\mathbf{X} \\
\text { Dorset }\end{array}$ \\
\hline $1955^{b}$ & $.59(15)$ & $.67(17)$ & $.64(11)$ & & \\
\hline $1956^{\mathrm{e}}$ & $.62(16)$ & $.66(17)$ & $.69(13)$ & & \\
\hline $1957^{d}$ & $.59(28)$ & $.60(30)$ & $.61(26)$ & $.57(5)$ & $.61(3)$ \\
\hline $1958^{d}$ & $.57(48)$ & $.56(35)$ & $.56(46)$ & $.55(5)$ & $.57(7)$ \\
\hline $1959^{a}$ & $.61(52)$ & $.58(43)$ & $.60(52)$ & $.59(19)$ & $.61(15)$ \\
\hline $1960^{\mathrm{d}}$ & $.59(47)$ & $.59(33)$ & $.59(49)$ & $.58(17)$ & $.59(16)$ \\
\hline
\end{tabular}

TABLE 6

Average Lamb Grade by Breed of Dam's Sire and Year ${ }^{d}$

\begin{tabular}{lccccc}
\hline \hline & & & Hampshire & $\begin{array}{c}\text { Dorset } \\
\text { X }\end{array}$ \\
Year & Corriedale & Hampshire & Dorset & Hampshire & Dorset \\
\hline $1955^{\mathrm{a}}$ & 2.2 & 2.1 & 1.7 & & \\
$1956^{\mathrm{b}}$ & 2.2 & 1.5 & 1.2 & & \\
$1957^{\mathrm{a}}$ & 1.8 & 1.6 & 1.6 & 1.8 & 2.0 \\
$1958^{\mathrm{a}}$ & 2.2 & 2.0 & 2.0 & 1.8 & 1.9 \\
$1959^{\mathrm{a}}$ & 3.2 & 3.3 & 3.0 & 3.1 & 2.8 \\
$1960^{\mathrm{c}}$ & 3.6 & 3.3 & 3.3 & 3.0 & 3.6 \\
\hline
\end{tabular}

a-No significant differences.

b-D graded higher than $\mathrm{C}(\mathrm{P}<0.01) ; \mathrm{H}$ graded higher than $\mathrm{C}(\mathrm{P}<0.05)$. actions of these with breed were separated first.

5 per cent level (Table 6). In 1960 the lambs from the double-bred Hampshires graded significantly higher than the lambs from the doublebred Dorset and the Corriedale-sired ewes at the 5 per cent level.

\section{WOOL YIELD AND LONGEVITY}

Ewes from Corriedale breeding produced more wool than the double-bred Hampshire $(\mathrm{P}<0.01)$ and the Dorset-sired $(\mathrm{P}<0.05)$ ewes (Table 7).

There were insufficient numbers of ewes born in any one year to test statistically for differences in longevity. 
Wool Yield and Longevity by Breed

\begin{tabular}{|c|c|c|c|c|c|}
\hline & Corriedale & Hampshire & Dorset & $\begin{array}{l}\text { Hampshire } \\
\mathrm{X} \\
\text { Hampshire }\end{array}$ & $\begin{array}{l}\text { Dorset } \\
\mathrm{X} \\
\text { Dorset }\end{array}$ \\
\hline No. Ewes & 43 & 44 & 46 & 30 & 22 \\
\hline Wool Yield (pounds) ${ }^{c}$ & $11.2^{\mathrm{a}, \mathrm{b}}$ & 9.6 & $8.4^{b}$ & $7.8^{\mathrm{a}}$ & 9.7 \\
\hline Longevity (per cent) ${ }^{d}$ & 84 & 87 & 78 & 71 & 68 \\
\hline
\end{tabular}

a-Group C differed from group HH $(\mathrm{P}<0.01)$.

$\mathrm{b}-$-Group $\mathrm{C}$ differed from group $\mathrm{D}(\mathrm{P}<0.05)$.

c-Average of 4 years (or less if culled earlier).

d-Measured as the percentage of ewes staying in the flock four years or longer. No test for differences was made due to insufficient numbers born in any one year.

\section{Conclusions}

It is difficult to compare the different breeds of ewes retained for flock replacement. There are many factors to be considered when making the decision as to which breed of rams to use on the various breeds of ewes for flock replacement. It is necessary to consider wool production, lambing percentage, and longevity of the ewes retained and their ability to transmit fast and efficient gaining ability to their lambs. Market demands must be considered; specifically, whether heavy or light lambs are desired and the quality or grade of the lambs demanded by the consumer.

Lambs from the Hampshire-sired ewes were slightly heavier at birth and their rate of gain was slightly greater than other breeds studied. The slaughter grade was also greater than for the other breeds. Wool production of these ewes was not as great as the Corriedale but was equal to the wool production of the Dorset.

The Corriedale-sired ewes gave birth to the greatest number of lambs per ewe bred but the per cent of these reaching market age did not differ significantly from the other breeds. The slaughter grade was slightly lower than that of lambs from either the Dorset- or Hampshiresired ewes.

Birth weights of lambs from the Dorset-sired ewes were as great as those from of the Corriedale-sired ewes but not as heavy as the Hampshire lambs. Average daily gain of the Dorset lambs was no better than the other breeds studied four out of six years. Mortality tended to be lower.

The double-bred ewes, both Dorset and Hampshire, tended to produce lambs that were lighter at birth, made slightly less gain, and graded lower at market than lambs from the single crosses studied. 
From this study it would be difficult to rank any one breed over the other in all traits. The choice would depend to a great extent on personal preference, availability of the breed, and market demands.

\section{Summary}

Results of comparison of different produìction traits of ewes sired by different breeds of rams for flock replacement are reported. The study covered a period of six years (1955-1960). Ewe lambs were retained which were from Corriedale, Hampshire, and Dorset sires out of crossbred western ewes and also from Hampshire- and Dorset-sired ewes. This study was conducted at the Reymann Memorial Farms, a substation of the West Virginia University Agricultural Experiment Station. A total of 150 Corriedale-sired, 150 Hampshire-sired, 154 Dorset-sired, 59 doublebred-Hampshire, and 41 double-bred-Dorset ewes were involved in this study. Comparisons were made of the lambs from these ewes bred to Corriedale, Hampshire, and Dorset rams on the following traits: lambs born and raised per ewe exposed, birth weight, rate of gain, live slaughter grade and livability. Wool production of the ewes retained was also studied.

The data showed only small differences among the various breeding groups of ewes. The most consistent differences were in birth weight, where Hampshire-sired ewes excelled, and in wool production, where Corriedale-sired ewes were outstanding.

\section{Literature Cited}

1. Livesay, E. A. and C. J. Cunningham, Native Hampshire Ewes vs. Western Corriedale Type Ewes for Lamb and Wool Production and Longevity, W. Va. Agr. Expt. Sta. Bull. 398, 1957.

2. Cunningham, C. J., B. W. Wamsley, J. A. Welch, and J. O. Heishman, A Comparison of Three Breeds of Rams as Sires of Market Lambs, W. Va. Agr. Expt.
Sta. Bull. 505, 1965. 3. Carter, R. C., C. M. Kincaid, J. A. Gaines, and G. W. Litton, Breed of Ram for
Spring Lamb Production, Va. Agr. Expt. Sta. Bull. 492, 1958 . 

